Part of Journal of Research of the National Bureau of Standards, Volume 26, May 1941

\title{
METHOD FOR DETERMINING THE COMPONENTS OF ASPHALTS AND CRUDE OILS
}

\author{
By 0. G. Strieter ${ }^{1}$
}

\section{ABSTRACT}

The ordinary procedure for the analysis of asphalts, which uses petroleum naphtha and carbon bisulfide as solvents, does not yield satisfactory results. Recently it has been found that by substituting pentane for the petroleum naphtha and ether for the carbon bisulfide, accurately reproducible results can be obtained for the content of asphaltenes, resins, and the oily constituents.

\section{CONTENTS}

I. Introduction $\quad$ Page

II. Revised procedure

1. Asphaltenes.

2. Oily constituents _...

3. Asphaltic resins

III. Analytical data

\section{INTRODUCTION}

The components of asphalt, according to Marcusson, ${ }^{2}$ are the asphaltic acids and their anhydrides, oily constituents, resins, and asphaltenes. The asphaltic acids and their anhydrides are determined by saponifying with cold and hot alcoholic potash, respectively, but owing to the formation of troublesome emulsions and to the fact that they are present in the asphalt only in small amounts, their determination is usually omitted, so the ordinary procedure is:

1. The asphaltenes are precipitated with $88^{\circ}$ Bé petroleum naphtha.

2. The petroleum naphtha filtrate, which contains the oily constituents and the resins, is reduced in volume by evaporation and then is completely absorbed by fuller's earth.

3. The oily constituents are extracted from the fuller's earth with petroleum naphtha.

4. After the oily constituents are removed from the fuller's earth, the resins are extracted with carbon bisulfide or benzol.

Petroleum naphtha is not a definite compound, but a mixture of hydrocarbons that varies with the nature of the crude petroleum from which it is obtained. A naphtha that consists chiefly of hydrocarbons of the paraffin series will precipitate the asphaltenes more

${ }^{1}$ Research Associate at the National Bureau of Standards, representing the Asphalt Roofing Industry Bureau.

${ }^{2}$ Herbert Abraham, Asphalt and Allied Substances, 4th ed., p. 1007. (D. Van Nostrand Co., Inc., New York, N. Y.) 1938. 
completely than will a naphtha of the same boiling range but composed of naphthenes and aromatics. The revised method substitutes $n$-pentane for the petroleum naphtha. Because $n$-pentane is of nearly constant composition, it has the advantage over petroleum naphtha that different lots of it will precipitate the same percentage of asphaltenes from a given sample of asphalt or of crude oil. In addition, because it is a paraffin hydrocarbon, it will precipitate the asphaltenes almost completely, and will give more accurate results than are possible to get with petroleum naphtha.

For the extraction of the resins from the fuller's earth, the revised method substitutes ethyl ether for the carbon bisulfide or benzol ordinarily used. On a given sample, it was found that extraction of the resins with carbon bisulfide yielded 8.3 percent and with benzol 13.2 percent, but extraction with ethyl ether according to the revised procedure yielded 22.7 percent. In these cases, the sums of the components of the asphalt when using carbon bisulfide, benzol, and ether, were 88.1, 94.7, and 99.4 percent, respectively.

\section{REVISED PROCEDURE}

Weigh $5.000 \mathrm{~g}$ of asphalt in small pieces on a tared watchglass and transfer to a $400-\mathrm{ml}$ wide-mouthed Erlenmeyer flask. Add $100 \mathrm{ml}$ of normal pentane, and rotate the Erlenmeyer flask until the asphalt is partially disintegrated. Add an additional $75 \mathrm{ml}$ of pentane, and again rotate until the asphalt is completely disintegrated. Then add $50 \mathrm{ml}$ of pentane, lightly cork the flask, and allow to settle overnight.

\section{ASPHALTENES}

Filter the pentane solution through a tared Gooch crucible, with slight suction. Catch the filtrate, without attempting to transfer all the asphaltenes to the Gooch crucible, in a $600-\mathrm{ml}$ beaker under a bell jar. Wash the residue in the flask and on the crucible with successive small portions of pentane until the filtrate is colorless. Dry the Gooch crucible in an oven at $105^{\circ} \mathrm{C}$, cool in a desiccator, and weigh. Dissolve in carbon tetrachloride the residue adhering to the walls of the Erlenmeyer flask, and transfer the solution to a 250-ml beaker. Evaporate to dryness by allowing the beaker to stand in a warm place, dry at $105^{\circ} \mathrm{C}$, and weigh. The combined weights of the residue divided by 5 and multiplied by 100 gives the percentage of asphaltenes.

\section{OILY CONSTITUENTS}

Allow the filtrate containing the oily constituents and the resins (600-ml beaker) to evaporate slowly to dryness at room temperature under the hood. Wash the sides of the beaker with pentane, and dissolve the residue in a total volume of $25 \mathrm{ml}$ of pentane.

To the $25-\mathrm{ml}$ pentane solution in the $600-\mathrm{ml}$ beaker add $20 \mathrm{~g}$ of fuller's earth which passes a 100-mesh screen, and thoroughly mix with a steel spatula. Add $15 \mathrm{~g}$ of 30 - to 60 -mesh fuller's earth, and mix with the finer fuller's earth to make the latter more porous.

Transfer the fuller's earth mixture, not too wet but before it becomes dusty, to a Soxhlet extraction thimble ( $43 \mathrm{~mm}$ in diameter and 123 
$\mathrm{mm}$ high). Plug the top of the thimble with cotton to prevent washing the fuller's earth out of the thimble during the subsequent extraction. Let the thimble with its contents stand for 4 hours, then place it in a Soxhlet extraction apparatus, cover with pentane, and allow to soak overnight. Extract with pentane for 6 hours, and again allow the thimble to soak overnight. Then extract for an additional 6 hours. (Place glass beads in the distilling flask to prevent bumping). Transfer the pentane solution, a little at a time, to a $250-\mathrm{ml}$ beaker and evaporate at room temperature under the hood. The beaker must never be more than half-filled, otherwise the evaporation of the pentane will cause the oily constituents to creep over its rim. Place the beaker on the steambath and then in an oven at $105^{\circ} \mathrm{C}$ to drive off the last traces of pentane, cool in a desiccator, and weigh. The weight of the oily constituents divided by 5 and multiplied by 100 gives the percentage of them in the sample. The oily constituents should be amber colored. If darker they must be treated again with fuller's earth and reextracted.

\section{ASPHALTIC RESINS}

After the removal of the oily constituents, extract the fuller's earth in the thimble with ethyl ether in the manner described for the oily constituents. Evaporate the ether solution to dryness, heat in an oven at $105^{\circ} \mathrm{C}$, cool, and weigh. The weight of the residue divided by 5 and multiplied by 100 gives the percentage of asphaltic resins.

\section{ANALYTICAL DATA}

Table 1 illustrates the type of analytical results obtained with the revised method, using pentane and ether as solvents.

The results given in table 1 are the average of two determinations. The duplicate asphaltene determinations varied by less than 0.3 percent. The maximum difference between determinations of the oily constituents was 1.5 percent and of the resins 1.0 percent.

TABLE 1.-Composition of four asphalts determined by the revised method

\begin{tabular}{|c|c|c|c|c|}
\hline Components & A & B & $\mathrm{C}$ & $\mathrm{D}$ \\
\hline $\begin{array}{l}\text { Asphaltenes } \\
\text { Oily constituents } \\
\text { Resins }\end{array}$ & $\begin{array}{l}\% \\
40.1 \\
41.0 \\
18.2\end{array}$ & $\begin{array}{l}\% \\
48.3 \\
33.2 \\
17.8\end{array}$ & $\begin{array}{l}\% \\
36.7 \\
40.0 \\
22.7\end{array}$ & $\begin{array}{l}\% \\
44.9 \\
39.0 \\
15.5\end{array}$ \\
\hline Total_. & 99.3 & 99.3 & 99.4 & 99.4 \\
\hline
\end{tabular}

The revised method is applicable not only to asphalts but to crude oils as well. Hence, every crude oil can be classified with respect to the proportion of asphaltenes, resins, and oily constituents that it contains. This is illustrated by the analysis of various crude oils as shown in table 2 . In this table the percentages of the oily constitu- 
ents were obtained by difference. The oily constituents of the crude oils are volatile and so can not be determined directly without a slight change in technic.

TABLE 2.-Analysis of crude oils by the revised method

\begin{tabular}{|c|c|c|c|c|}
\hline Specimen & Source & $\begin{array}{c}\text { Asphal- } \\
\text { tenes }\end{array}$ & $\begin{array}{l}\text { Oily con- } \\
\text { stituents }\end{array}$ & Resins \\
\hline 10 & $\begin{array}{c}\text { Arkansas } \\
\text { Texas } \\
\text { do do } \\
\text { California } \\
\text { Kentucky } \\
\text { Kento }\end{array}$ & $\begin{array}{r}\% \\
4.3 \\
7.2 \\
5.5 \\
7.7 \\
6.7 \\
17.5 \\
9.8 \\
0.1\end{array}$ & $\begin{array}{r}\% \\
79.9 \\
76.6 \\
80.7 \\
77.9 \\
74.7 \\
63.7 \\
75.4 \\
95.8\end{array}$ & $\begin{array}{r}\% \\
15.8 \\
16.2 \\
13.8 \\
14.4 \\
18.6 \\
18.8 \\
14.8 \\
4.1\end{array}$ \\
\hline
\end{tabular}

Washington, February 25, 1941. 